\title{
Attitude of Farmers towards Agriculture
}

\author{
M.S. Nataraju, M.T. Lakshminarayan, Preethi" and K.C. Lalitha \\ Director of Extension, University of Agricultural Sciences, Hebbal Bengaluru, India \\ *Corresponding author
}

\section{A B S T R A C T}

\section{Keywords \\ Attitude, Farmers, Agriculture, Fragmentation, Land holding}

\section{Article Info}

Accepted:

17 December 2018 Available Online: 10 January 2019
The present study was undertaken during 2017-2019 in Bangalore Rural District of Karnataka state to analyze the attitude of farmers towards agriculture. One hundred agricultural households in rural areas of North transect formed the sample of the study. More than three-fourth (77\%) of the farmers had favourable to more favourable attitude towards agriculture. Education, employment, risk orientation, innovative proneness, life style, mass media participation and extension participation of farmers were having a positive and significant to highly significant relationship with their attitude towards agriculture. For every unit increase in the education, employment, risk orientation, innovative proneness, life style, mass media participation and extension participation of farmers there will be more favorableness of attitude towards agriculture. Fragmentation of land into unconventional shape and size (92\%), lack of infrastructure in rural areas $(86 \%)$ and inadequate training and extension services (86\%) were the important three factors influencing the attitude of farmers towards agriculture.

\section{Introduction}

Agriculture is the mainstay of Indian economy, where in a tone of grave respect refers to the farmer as the 'annadata' -the provider of grain. This is because in India, agriculture has been the life and the means of sustenance for the majority of the people. Even today, more than half of the country's population is directly and indirectly dependent upon agriculture (Onima et al., 2017). Attitude is the degree of positive or negative disposition / association towards an innovation, object, programme, enterprise etc. (Likert, 1932). There is no limit to the topics which people may have attitudes. Hence, it can be persuasively argued that everything in life depends on attitude. The success and failure of any enterprise mainly depends upon the people's mindset or attitude towards a particular enterprise, hence attitude of a farmer plays an important role in accepting or rejecting the enterprise. In this background, the present was undertaken with the following specific objectives:

To analyse the attitude of farmers towards agriculture and To understand the relationship and the extent of contribution of personal, socio-economic, psychological and communication characteristics of farmers on their attitude towards agriculture. Also the factors influencing the attitude of farmers 
towards agriculture

\section{Materials and Methods}

The present study was carried out in Bangalore Rural District of Karnataka state during 2017-2019. One hundred agricultural households in rural areas of North transect were interviewed using a schedule. Attitude of farmers towards agriculture was analyzed using an attitude scale consisting of 20 statements. The response for each statement was collected on a three point continuum namely, agree, undecided and disagree with assigned score of 3.2. and 1, respectively. One could get a minimum and maximum score of 20 and 60, respectively. The summed score of all the 20 statement obtained was considered as attitude score of individual respondent.

Information on 14 personal, socio-economic, psychological and communication characteristics of farmers were measured using suitable and standardized scale/procedure. Attitude of farmers towards agriculture was considered as dependent variable, while the farmers' characteristics were considered as independent variables. The collected data were analyzed using frequency, percentage, standard deviation and correlation test. Correlation test was employed to find out the relationship between personal, socio-economic, psychological and communication characteristics of farmers with their attitude towards agriculture.

\section{Results and Discussion}

\section{Statement-wise attitude of farmers towards agriculture}

In respect of the attitude score of farmers, it is observed that the attitude statements like: 'One should have passion towards agriculture to practice it', 'Being a farmer is the best job in the world', 'I enjoy the relationship with nature through agriculture', 'It is my privilege to sustain in agriculture' and 'I will encourage others to engage in agriculture' secured I, II, III, IV and V ranks, respectively (Table 1). The statements like 'I feel that I am feeding the world by practicing agriculture', 'One should be proud of being a member of a farm family practicing agriculture', I have freedom to work in my own way in agriculture', 'I can overcome any type of hardships in agriculture' and 'People who are able to take risks in agriculture are successful' was accorded VI, VII, VIII, IX and X ranks, respectively, by the farmers. Whereas, the attitude statements viz., 'Practicing agriculture is not stressful', 'I am proud to own farm land', 'I have freedom to work in my own way in agriculture', 'Agriculture is viewed as a respectable profession in the society' and 'Agriculture could be practices by both illiterates and literates' were accorded the XVI, XVII, XVIII, XIX and XX ranks, respectively. It can be inferred that most of the farmers had 'agreed' for all the statements measuring the attitude towards agriculture. The findings denote that the farmers have favourable attitude towards agriculture.

\section{Overall attitude of farmers towards agriculture}

It is observed from Table 2 that more number of farmers $(42.00 \%)$ had favourable attitude towards agriculture, while 35.00 and 23.00 per cent of farmers were having more favourable and less favourable attitude towards agriculture, respectively. It can be concluded that as high as 77 per cent of the farmers had favourable to more favourable attitude towards agriculture. Availability of improved agricultural technologies, employment throughout the year in farm activities, regular and decent income from agriculture, accessibility of gross root extension functionaries and adequate opportunities to participate in extension 
activities are the reasons for over three fourth (77\%) of the farmers possessing favourable to more favourable attitude towards agriculture.

Relationship and extent of contribution of personal, socio-economic and psychological characteristics of farmers on their attitude towards agriculture

A bird's eye view of Table 3 reveals that age, family size, farming experience, land holding, annual income, social participation and life satisfaction of rural, peri-urban and urban areas of farmers were having a positive and non- significant relationship with their attitude towards agriculture.

Variables such as, education, employment, risk orientation, innovative proneness, life style, mass media participation and extension participation of farmers were having a positive and significant to highly significant relationship with their attitude towards agriculture. For every unit increase in the education, employment, risk orientation, innovative proneness, life style, mass media participation and extension participation of farmers there will be more favorableness of attitude towards agriculture.

The finding revealed that education, employment, risk orientation, innovative proneness, life style, mass media participation and extension participation of farmers have significantly contributed in developing favourable attitude towards agriculture. The contribution of 14 selected socio-economic, psychological and communication characteristics of farmers had contributed to the tune of 66.50 per cent of variation in developing favorable attitude towards agriculture.

Table.1 Statement -wise attitude of farmers towards agriculture

\begin{tabular}{|c|c|c|c|}
\hline \multirow[t]{2}{*}{ Sl. No. } & \multirow[t]{2}{*}{ Statements } & \multicolumn{2}{|c|}{ Farmers } \\
\hline & & Score & Rank \\
\hline 1 & Being a farmer is the best job in the world & 241 & II \\
\hline 2 & Practicing agriculture is not stressful & 200 & XVI \\
\hline 3 & Agriculture could be practices by both illiterates and literates & 167 & $\mathrm{XX}$ \\
\hline 4 & I prefer to be a farmer than as an employee & 217 & XII \\
\hline 5 & I enjoy the relationship with nature through agriculture & 240 & III \\
\hline 6 & Agriculture is viewed as a respectable profession in the society & 189 & XIX \\
\hline 7 & I am proud to own farm land & 199 & XVII \\
\hline 8 & I feel agriculture is more profitable than any other occupation & 213 & XIII \\
\hline 9 & I am ready to invite innovations in agriculture & 213 & XIII \\
\hline 10 & I can overcome any type of hardships in agriculture & 224 & IX \\
\hline 11 & I want to continue in agriculture further... & 203 & $\mathrm{XV}$ \\
\hline 12 & People who are able to take risks in agriculture are successful & 225 & IX \\
\hline 13 & I feel that I am feeding the world by practicing agriculture & 237 & VI \\
\hline 14 & I will encourage others to engage in agriculture & 238 & IV \\
\hline 15 & I have freedom to work in my own way in agriculture & 231 & VIII \\
\hline 16 & One should have passion towards agriculture to practice it & 246 & I \\
\hline 17 & It is my privilege to sustain in agriculture & 238 & IV \\
\hline 18 & I prefer to take risks in agriculture at any cost & 220 & XI \\
\hline 19 & $\begin{array}{l}\text { One should be proud of being a member of a farm family practicing } \\
\text { agriculture }\end{array}$ & 233 & VII \\
\hline 20 & Agriculture is not just a occupation, but it a way of life & 195 & XVIII \\
\hline
\end{tabular}


Table.2 Overall attitude of farmers towards agriculture $(n=100)$

\begin{tabular}{|c|l|c|c|}
\hline \multirow{2}{*}{$\begin{array}{c}\text { Sl. } \\
\text { No. }\end{array}$} & \multirow{2}{*}{$\begin{array}{c}\text { Attitude } \\
\text { category }\end{array}$} & \multicolumn{2}{|c|}{ Farmers } \\
\cline { 2 - 4 } $\mathbf{1}$ & Less favourable & 23 & 23.00 \\
\hline $\mathbf{2}$ & Favourable & 42 & 42.00 \\
\hline $\mathbf{3}$ & More favourable & 35 & 35.00 \\
\hline & Total & 100 & 100.00 \\
\hline \multicolumn{2}{|c|}{ Mean } & \multicolumn{3}{|c|}{43.69} \\
\hline \multicolumn{2}{|c|}{ Standard deviation } & \multicolumn{3}{|c|}{7.36} \\
\hline
\end{tabular}

Table.3 Relationship and extent of contribution of personal, socio-economic and psychological characteristics of farmers on their attitude towards agriculture $(n=100)$

\begin{tabular}{|c|l|c|}
\hline Sl. No. & \multicolumn{1}{|c|}{ Characteristics } & $\begin{array}{c}\text { Correlation } \\
\text { co-efficient } \\
\text { ('r' value) }\end{array}$ \\
\hline $\mathbf{1}$ & Age & $0.091^{\mathrm{NS}}$ \\
\hline $\mathbf{2}$ & Education & $0.292^{* *}$ \\
\hline $\mathbf{3}$ & Family size & $0.076^{\mathrm{NS}}$ \\
\hline $\mathbf{4}$ & Farming experience & $0.011^{\mathrm{NS}}$ \\
\hline $\mathbf{5}$ & Land holding & $0.045^{\mathrm{NS}}$ \\
\hline $\mathbf{6}$ & Employment & $0.200^{*}$ \\
\hline $\mathbf{7}$ & Annual income & $0.009^{\mathrm{NS}}$ \\
\hline $\mathbf{8}$ & Risk orientation & $0.234^{*}$ \\
\hline $\mathbf{9}$ & Social participation & $0.076^{\mathrm{NS}}$ \\
\hline $\mathbf{1 0}$ & Innovative proneness & $0.345^{* *}$ \\
\hline $\mathbf{1 1}$ & Life style & $0.212^{*}$ \\
\hline $\mathbf{1 2}$ & Life satisfaction & $0.082^{\mathrm{NS}}$ \\
\hline $\mathbf{1 3}$ & Mass media participation & $0.227^{*}$ \\
\hline $\mathbf{1 4}$ & Extension participation & $0.333^{* *}$ \\
\hline NS=Non-significant; $*$ Significant at $5 \% * *$ & Significant at $1 \%$ \\
\hline & & \\
\hline
\end{tabular}


Table.4 Factors influencing attitude of farmers towards agriculture $(n=100)$

\begin{tabular}{|c|c|c|c|}
\hline \multirow[b]{2}{*}{ Sl. No. } & \multirow[b]{2}{*}{ Factors* } & \multicolumn{2}{|c|}{ Farmers } \\
\hline & & Number & Per cent \\
\hline 1 & Insufficient land & 81 & 81.00 \\
\hline 2 & Lack of infrastructure in rural areas & 86 & 86.00 \\
\hline 3 & Inadequate training and extension services & 86 & 86.00 \\
\hline 4 & $\begin{array}{l}\text { Fragmentation of land into unconventional shape and } \\
\text { size }\end{array}$ & 92 & 92.00 \\
\hline 5 & Lack of conviction & 52 & 52.00 \\
\hline 6 & Non-availability of inputs in time & 74 & 74.00 \\
\hline 7 & Heavy risk due to failure of monsoon & 70 & 70.00 \\
\hline 8 & Expensiveness of agro-chemicals and seeds & 77 & 77.00 \\
\hline 9 & Low returns from crops/animals & 76 & 76.00 \\
\hline 10 & Lack of market facility & 67 & 67.00 \\
\hline 11 & Lack of storage facility & 60 & 60.00 \\
\hline 12 & Scarcity of labour & 84 & 84.00 \\
\hline 13 & Non-availability of agro-chemicals & 73 & 73.00 \\
\hline 14 & High wage rate & 82 & 82.00 \\
\hline 15 & Lack of knowledge on improved agriculture technology & 84 & 84.00 \\
\hline
\end{tabular}

* Multiple response

Factors influencing attitude of farmers towards agriculture

The findings in Table 4 indicate the factors influencing attitude of farmers towards agriculture. More than three-fourth of the farmers expressed that fragmentation of land into unconventional shape and size $(92 \%)$, lack of infrastructure in rural areas $(86 \%)$, inadequate training and extension services $(86 \%)$, scarcity of labour (84\%), lack of knowledge on improved agriculture technology (84\%), high wage rate $(84 \%)$, insufficient land $(81 \%)$, expensiveness of agro-chemicals and seeds (77\%) and low returns from crops/animals $(76 \%)$ are the major factors influencing the attitude towards agriculture. The other factors influencing the attitude of farmers towards agriculture were lack of conviction, non-availability of inputs in time, heavy risk due to failure of monsoon, lack of market and storage facility and nonavailability of agro-chemicals.
It can be concluded from the findings of the research study that a greater majority (77\%) of the farmers possess favourable to more favourable attitude towards agriculture. There is a need to provide educational opportunities (training, demonstrations, meetings, farmers field school, field tours etc.) for improving the knowledge of the farmers on improved agriculture technology, besides providing subsidies on agricultural inputs and extending marketing facilities by the concerned agencies.

\section{Acknowledgement}

This Research article is part of the IndoGerman Research Project entitled Attitudes and Decisions of Agricultural households in the Rural-Urban Interface: A Survey and Comparative Analysis I-B02 (GOI-381D) sponsored by Department of Bio-Technology, Government of India. The financial assistance given by DBT is duly acknowledged. 


\section{References}

Likert, R.A., 1932, A technique for the measurement of attitudes. Mysore J. Agril. Sci., 46 (4): 868-873.
Onima, V.T., Timbadia, C.K., Gulkari, K.D. and Bhuva, R.M., 2017, Attitude of farmers towards farming as an occupation, Int. J. Pure Biosci., 5 (5): 833-837.

\section{How to cite this article:}

Nataraju, M.S., M.T. Lakshminarayan, Preethi and Lalitha, K.C. 2019. Attitude of Farmers towards Agriculture. Int.J.Curr.Microbiol.App.Sci. 8(01): 2729-2734. doi: https://doi.org/10.20546/ijcmas.2019.801.288 